\title{
Analisis Kemampuan Pemahaman Matematis Siswa MTs Ditinjau Dari Disposisi Matematis Siswa
}

(Analysis of Students Mathematical Comprehension Ability MTs Reviewed From Student Mathematical Disposition)

\author{
Muhammad Rifal ${ }^{1}$, Kodirun $^{2} \&$ Lambertus $^{3}$ \\ ${ }^{1}$ Program PascaSarjana Pendidikan MatematikaUHO;email: muh94rifal@gmail.com \\ ${ }^{2}$ Pendidikan Matematika FKIP dan PPs UHO; email: kodirun_zuhry@yahoo.co.id \\ ${ }^{3}$ Pendidikan Matematika FKIP dan PPs UHO; email: lambertus_59@yahoo.co.id
}

\begin{abstract}
Abstrak: Tujuan dalam penelitian ini adalah mengungkapkan karakteristik kemampuan pemahaman matematis siswa kelas VII-B MTs Asy-syafi'iyah Kendari dengan tingkat disposisi matematis tinggi, disposisi matematis sedang dan disposisi matematis rendah pada materi Bentuk Aljabar. Jenis penelitian yang digunakan pada penelitian ini adalah penelitian kualitatif yang menggunakan pendekatan deskriptif. Instrumen dalam penelitian ini ada dua macam, yaitu instrumen utama dan instrument bantu. Instrumen utama adalah peneliti itu sendiri, sedangkan instrumen bantu ada 3 (tiga) macam yaitu, tes disposisi, tes pemahaman matematis, dan pedoman wawancara. Pengumpulan data dilakukan dengan pemberian tes dan wawancara.Data kemampuan pemahaman matematis yang diperoleh selanjutnya dilakukan triangulasi waktu melalui pemberian masalah baru yang setara untuk diselesaikan pada waktu yang berbeda. Teknik analisis data dalam penelitian dilakukan berdasarkan model Milles dan Huberman yang meliputi reduksi data, penyajian data, dan penarikan kesimpulan. Berdasarkan hasil penelitian menunjukkan bahwa: 1) subjek disposisi matematis tinggi (DMT) mampu memahami konsep-konsep dan fakta matematika dalam istilah konsep dan fakta matematika yang lebih sederhana yakni siswa dapat membuat pemisalan matematika dengan benar; mampu membuat hubungan logisantara fakta dan konsep yangberbeda yakni siswa membuat model matematika dengan benar; mampu mengaitkan hal yang telahdiketahui sebelumnya ketikamenemukan sesuatu yang baru baikdi dalam atau di luar matematika yakni siswa menyelesaikan permasalahan yang sudah diketahui dan dioperasikan; mampu mengidentifikasi prinsip-prinsip dalambagian tertentu dari matematika yang membuat semuanya saling berkaitan dalam menyelesaikan suatu masalah matematika yakni siswa menyimpulkan hasil dari permasalahan yang sudah diselesaikan; 2) subjek disposisi matematis sedang (DMS) dan subjek disposisi matematis rendah (DMR) belum mampu memenuhi semua indikator pemahaman matematis yakni siswa tidak dapat membuat pemisalan matematika dengan benar, siswa tidak dapat membuat model matematika dengan benar, siswa tidak dapat menyelesaikan permasalahan yang sudah diketahui dan dioperasikan, dan siswa tidak dapat menyimpulkan hasil dari permasalahan yang sudah diselesaikan.
\end{abstract}

Kata Kunci: Kemampuan pemahaman matematis dan disposisi matematis 


\begin{abstract}
Thepurpose of this study was to reveal the characteristics of mathematical comprehension ability of students in grade VII-B MTs Asy-syafi'iyah Kendari with high levels of mathematical disposition, moderate mathematical disposition and low mathematical disposition on algebraic form material.The type of research used in this research is qualitative research that uses descriptive approach. Instruments in this research there are two kinds, namely the main instrument and the auxiliary instrument. The main instruments are the researchers themselves, while the auxiliary instruments there are 3 (three) kinds namely, dispositiontests, mathematical comprehension tests, and interview guidelines. Data collection is done by providing tests and interviews. The mathematical comprehension capability data obtained is then triangulated time through the provision of new problems that are equivalent to be solved at different times. Data analysis techniques in the study were conducted based on Milles and Huberman models which include data reduction, data presentation, and conclusion drawing. Based on the results of the study showed that: 1) the subject of high mathematical disposition (DMT) is able to understand mathematical concepts and facts in terms of simpler mathematical concepts and facts, that is students can make mathematical assumptions correctly; able to make logical connections between different facts and concepts that isstudents create mathematical models correctly; able to relate previously known things when finding something new either inside or outside mathematics, namely students solving problems that are already known and operated; able to identify the principles in certain parts of mathematics that make everything interrelated in solving a mathematical problem, namely students conclude the results of problems that have been solved; 2) The subject of moderate mathematical disposition (DMS) and the subject of low mathematical disposition (DMR) have not been able to meet all the indicators of mathematical understanding the is student cannot make the math assessment correctly, the student cannot make the math model correctly, the student cannot solve the known and operated problem, and the student cannot conclude the results of the problem that has been solved.
\end{abstract}

Keywords: Ability to understand mathematically and mathematical disposition

\title{
PENDAHULUAN
}

Matematika merupakan salah satu mata pelajaran wajib pada semua jenjang pendidikan di sekolah. Mata pelajaran matematika dipelajari mulai jenjang sekolah TK, SD, SMP, SMA bahkan perguruan tinggi karena matematika digolongkan ke dalam subjek ilmu yang universal serta memiliki peranan penting dalam perkembangan ilmu pengetahuan dan dunia teknologi. Perkembangan ilmu pengetahuan yang begitu pesat juga mempengaruhi persaingan global yang terus meningkat, sehingga menuntut para pendidik untuk terus melahirkan para generasi yang mampu bersaing baik di tingkat nasional maupun internasional.

Permendiknas No. 22 tahun 2006 secara eksplisit mencantumkan beberapa kemampuan dan sikap siswa yang harus dikembangkan sebagai tujuan dari pembelajaran matematika. Beberapa kemampuan dan sikap itu adalah: 
1. Memahami konsep matematika, menjelaskan keterkaitan antar konsep dan mengaplikasikan konsep atau algoritma secara luwes, akurat, efisien dan tepat dalam pemecahan masalah;

2. Menggunakan penalaran pada pola dan sifat, melakukan manipulasi matematika dalam membuat generalisasi, menyusun bukti, atau menjelaskan gagasan dan pernyataan matematika;

3. Memecahkan masalah yang meliputi kemampuan memahami masalah, merancang model matematika, menyelesaikan model dan menafsirkan solusi yang diperoleh;

4. Mengkomunikasikan gagasan dengan simbol, tabel, diagram atau media lain untuk memperjelas keadaan, atau masalah; dan,

5. Memiliki sikap menghargai kegunaan matematika dalam kehidupan, yaitu memiliki rasa ingin tahu, perhatian, dan minat dalam mempelajari matematika, serta sikap ulet dan percaya diri dalam pemecahan masalah.

Dari seluruh kemampuan matematis menurut Depdiknas di atas, poin 1 sampai 4 merupakan kemampuan kognitif siswa dan poin 5 merupakan kemampuan afektif yang harus dimiliki siswa. Salah satu kemampuan kognitif yang penting untuk dimiliki adalah kemampuan pemahaman matematis.Sebagaimana yang dikemukakan oleh Santrock (Hendriana dkk, 2017) kemampuan pemahaman penting dimiliki karena kemampuan ini merupakan aspek kunci dari pembelajaran.Selain itu, kemampuan pemahaman matematis sangat sangat mendukung pada pengembangan kemampuan matematis lainnya, yaitu komunikasi, pemecahan masalah, penalaran, koneksi representasi, berpikir kritis, dan berpikir kreatif matematis serta kemampuan matematis lainnya. Pendapat serupa dikemukakan Wiharno (Hendriana dkk, 2017) bahwa kemampuan pemahamn matematis merupakan suatu kekuatan yang harus diperhatikan selama proses pembelajaran matematika, terutama untuk memperoleh pengetahuan matematika yang bermakna.

Kenyataannya yang terdapat di lapangan, banyak siswa yang belum mampu memahami permasalahan matematika sekalipun permasalahan yang diberikan berkenaan dengan materi yang sudah dipelajari. Hal ini juga dapat dilihat pada hasil tes TIMSS pada tahun 2015 (Trends in International Mathematics and Science Study) dan PIRLS (Progress in International Reading Literacy) International Study Center) melaporkan Indonesia berada pada posisi 36 dari 49 negara. Hasil ini merupakan suatu hal yang sangat membuat kita prihatin dan tidak bisa disepelekan karena pendidikan merupakan sektor terpenting yang mempengaruhi kualitas sumber daya manusia.Upaya ke arah meningkatkan sumber daya manusia tidak terlepas dari peningkatan kualitas pendidikan yang diselenggarakan di sekolah tersebut.Menurut Yuliati Palaki dan Fahinu (2015:154) guru dan siswa sebagai komponen sumber daya 
manusia harus mampu memperoleh, memilih dan mengelola informasi yang selalu berubah dan kompetitif.Kemampuan ini membutuhkan pemikiran yang kritis, sistematis, logis, kreatif, dan kemauan kerjasama yang kuat.Cara berpikir seperti ini dapat dikembangkan melalui belajar matematika karena matematika memiliki struktur dan keterkaitan yang kuat dan jelas antar konsepnya sehingga memungkinkan terampil berpikir rasional.

Kemampuan pemahaman matematis memberikan pengertian bahwa materimateri yang diajarkan kepada siswa bukan hanya sebagai hafalan, namun lebih dari itu menekankan pada pemahaman, dimana dengan pemahaman siswa dapat lebih mengerti akan konsep materi pelajaran itu sendiri. Pemahaman merupakan terjemahan dari istilah understanding yang diartikan sebagai penyerapan arti suatu materi yang dipelajari. Menurut Van de Walle "pemahaman dapat didefinisikan sebagai ukuran kualitas dan kuantitas hubungan suatu pengetahuan yang sudah ada. Pemahaman matematis juga merupakan salah satu tujuan dari setiap materi yang disampaikan oleh guru, sebab guru merupakan pembimbing siswa untuk mencapai konsep yang diharapkan. Hal ini sesuai dengan Hudoyo (Hendriana dkk, 2017) yang menyatakan: "tujuan mengajar adalah agar pengetahuan yang disampaikan dapat dipahami peserta didik" Pendidikan yang baik adalah usaha yang berhasil membawa siswa kepada tujuan yang ingin dicapai yaitu agar bahan yang disampaikan dipahami sepenuhnya oleh siswa.

Dari beberapa pendapat yang telah dipaparkan di atas mengenai pentingnya dan manfaat memiliki kemampuan pemahaman matematis tak lepas dari kendala atau kesulitan tersendiri yang dialami siswa dalam belajar matematika.Menurut Jamal (Rahayu dkk, 2018) kesulitan siswa dalam belajar matematika dapat disebabkan oleh faktor internal yaitu yang berasal dari diri siswa sendiri, misalnya kesehatan, bakat minat, motivasi intelegensi, dan lain sebagainya.Selain dari faktor internal, faktor eksternal atau faktor yang berasal dari luar diri siswapun dapat menjadi penyebab kesulitan siswa dalam belajar matematika, misalnya dari lingkungan keluarga, sekolah dan lingkungan masyarakat.Selain itu Tall \& Razali (Layn dkk, 2017) menyatakan bahwa kesalahan siswa dalam mengerjakan soal matematika terdapat dalam kesalahan konsep dan pemahaman dalam belajar.

Berdasarkan informasi yang didapatkan dari salah satu guru matematika MTs Asy-syafi'iyah, Ibu Yuslianti, S.Pd., menyatakan bahwa kemampuan siswa dalam memahami dan menyerapkan pelajaran masih kurang, karena siswa biasanya hanya menghafal rumus dan hanya mengikuti langkah-langkah yang diajar oleh guru tanpa memahami cara dalam mengubah soal cerita ke dalam bentuk matematis. Siswa hanya bisa menjawab soal cerita yang di buat oleh guru sama persis, namun ketika soalnya diubah maka siswa tidak bisa menjawabnya lagi karena mereka hanya 
terpaku dan menghafal pada contoh soal yang diajarkan. Selanjutnya, ibu Yuslianti menjelaskan bahwa $80 \%$ dari jumlah keseluruhan siwa jika diberikan soal cerita, mampu menuliskan diketahui atau memisalkan dan ditanyakan namun mungkin, karena siswa kurang teliti dan memahami dalam menerima informasi dari soal sering terjadi kesalahan pada memisalkan suatu masalah, siswa juga sangat kurang mampu membuat hubungan logis antara fakta dan konsep yang berbeda, hal ini terlihat dari cara siswa membuat model matematika yang kurang tepat, kebanyakan siswa juga masih tidak mampu melakukan operasi matematika terkait soal yang diberikan, dan terkait penarikan kesimpulan dari masalah siswa bisa mengumpulkan informasi, namun salah karena tidak mengikuti atuaran dalam menyelesaikan masalah. Jika dipandang dari segi pemahaman matematis dapat disimpulkan bahwa siswa mampu memenuhi salah satu indikator pemahaman matematis yaitu mampu memahami konsep-konsep dan fakta matematika dalam dalam istilah konsep dan fakta matematika yang lebih sederhana walaupun masih banyak kesalahan.

Hudojo (2005: 48) meyatakan "secara sederhana matematika mempunyai beberapa karakteristik yaitu matematika memiliki objek kajian yang abstrak, bertumpu pada kesepakatan, berpola pikir deduktif, konsisten dalam sistemnya, memiliki atau menggunakan simbol yang kosong dari arti dan memperhatikan semesta pembicaraan.

Suherman, dkk (2003: 15) menyatakan istilah matematika mulanya diambil dari perkataan mathematika yang berarti berhubungan dengan belajar (berpikir).Perkataan itu mempunyai akar kata mathema yang berarti pengetahuan atau ilmu.

Menurut James sebagaimana dikutip oleh Suherman, dkk (2003: 16) matematika adalah ilmu tentang logika mengenai bentuk, susunan, besaran, dan konsep-konsep yang berhubungan antara satu dengan yang lainnya dengan jumlah yang banyak yang terbagi ke dalam tiga bidang yaitu aljabar, analisis, dan geometri. Menurut Kline, (Suherman dkk., 2003: 17) dengan adanya matematika dapat membantu manusia dalam memahami dan menguasai permasalahan sosial, ekonomi dan alam. Oleh karena itu, dengan mempelajari matematika yang terbagi ke dalam tiga bidang yaitu aljabar, analisis dan geometri dapat membantu manusia menguasai permasalahan sosial dan ekonomi.

Menurut Gagne, sebagaimana dikutip oleh Suherman, dkk (2003: 33) dalam belajar matematika ada dua objek yang dapat diperoleh siswa, yaitu objek tak langsung berupa kemampuan menyelidiki dan memecahkan masalah, belajar mandiri, sikap positif terhadap matematika, dan cara belajar. Sedangkan objek langsung berupa: (1) fakta yaitu objek matematika yang tinggal menerimanya, seperti lambang bilangan, sudut dan notasi-notasi lainnya; (2) keterampilan berupa 
kemampuan memberikan jawaban dengan cepat dan tepat, misalnya melakukan pembagian bilangan yang cukup besar, (3) konsep yaitu ide abstrak yang memungkinkan kita dapat mengelompokkan objek ke dalam contoh dan bukan contoh, misalkan konsep pecahan, bilangan prima, himpunan dan vektor; dan (4) aturan yaitu objek yang paling abstrak yang berupa sifat atau teorema.

Pemahaman merupakan bagian yang sangat penting dalam proses belajar mengajar dan memecahkan masalah, baik dalam proses belajar itu sendiri maupun di dalam kehidupan nyata. Kemampuan memahami konsep menjadi landasan untuk berfikir dan menyelesaikan persoalan. Menurut Walle (2008: 26)." Pemahaman dapat didefinisikan sebagai ukuran kualitas dan kuantitas hubungan suatu ide dengan ide yang telah ada".Setiap siswa memiliki kemampuan pemahaman yang berbeda tergantung pada ide yang dimiliki dan pembuatan hubungan antara ide yang ada dengan ide baru.

Bloom (Suherman, 2003: 29-35) mengklasifikasikan pemahaman pada jenjang kognitif urutan kedua setelah pengetahuan, jenjang kognitif tahap pemahaman ini mencakup yaitu:

a. Pemahaman konsep;

b. Pemahaman prinsip, aturan, dan generalisasi;

c. Pemahaman terhadap struktur matematika;

d. Kemampuan untuk membuat tranformasi;

e. Kemampuan untuk mengikuti pola berpikir;

f. Kemampuan untuk membaca dan menginterpretasikan masalah sosial atau data matematika.

Pemahaman akan sebuah konsep ilmu pengetahuan yang sedang dipelajari memiliki peranan yang sangat penting. Siswa akan berkembang ke jenjang kognitif yang lebih tinggi jika ia memiliki pemahaman konsep yang baik. Jika pemahaman konsep dikuasai dengan baik maka siswa akan mampu menghubungkan atau mengaitkan sebuah konsep yang satu dengan yang lainnya. Selain itu, konsep tersebut dapat digunakan untuk memecahkan permasalahan dari mulai yang sederhana hingga ke permasalahan yang lebih komplek.

Sementara itu, Skemp (Idris, 2009: 37) membedakan pemahaman ke dalam tiga macam, yaitu:

a. Pemahaman instrumental (instrumental understanding)

b. Pemahaman relasional (relational understanding)

c. Pemahaman logis (logical understanding)

Pemahaman instrumental adalah kemampuan seseorang menggunakan prosedur matematis untuk menyelesaikan suatu masalah tanpa mengetahui mengapa prosedur itu digunakan. Dengan kata lain siswa hanya mengetahui "bagaimana" 
tetapi tidak mengetahui "mengapa". Pada tahapan ini, pemahaman konsep masih terpisah dan hanya sekedar hafal suatu rumus untuk menyelesaikan permasalahan rutin/sederhana sehingga siswa belum mampu menerapkan rumus tersebut pada permasalahan baru yang berkaitan.Sementara itu, pemahaman relasional adalah kemampuan seseorang menggunakan prosedur matematis dengan penuh kesadaran bagaimana dan mengapa prosedur itu digunakan.Secara ringkasnya, siswa mengetahui keduanya yaitu "bagaimana" dan "mengapa". Pada tahap ini, siswa dapat mengaitkan antara satu konsep atau prinsip dengan konsep atau prinsip lainnya dengan benar dan menyadari proses yang dilakukan. Sedangkan pemahaman logis berkaitan erat dengan meyakinkan diri sendiri dan meyakinkan orang lain. Dengan kata lain, siswa dapat mengkonstruksi sebuah bukti sebelum ide-ide yang dimilikinya dipublikasikan secara formal atau informal sehingga membuat siswa tersebut merasa yakin untuk membuat penjelasan kepada siswa yang lain.

Berdasarkan teori-teori di atas, dapat disimpulkan bahwa pemahaman matematis adalah pengetahuan siswa terhadap konsep, prinsip, prosedur dan kemampuan siswa menggunakan strategi penyelesaian terhadap suatu masalah yang disajikan. Seseorang yang telah memiliki kamampuan pemahaman matematis berarti orang tersebut telah mengetahui apa yang dipelajari, langkah-langkah yang telah digunakan, dapat menggunakan konsep dalam konteks matematika dan diluar konteks matematika. Indikator pemahaman matematis dalam penelitian ini, maka peneliti menggunakan indikator dari Afled, yaitu:

a. Mampu memahami konsep-konsep dan fakta matematika dalam dalam istilah konsep dan fakta matematika yang lebih sederhana

b. Mampu membuat hubungan logis antara fakta dan konsep yang berbeda.

c. Mampu mengaitkan hal yang telah diketahui sebelumnya ketika menemukan sesuatu yang baru baik di dalam atau di luar matematika.

d. Mengidentifikasi prinsip-prinsip dalam bagian tertentu dari matematika yang membuat semuanya saling berkaitan dalam menyelesaikan suatu masalah matematika.

Menurut Karlimah (Shodikin, 2015) dalam proses pembelajaran hal yang penting untuk dikembangkan tak hanya kemampuan kognitif namun juga kemampuan afektif (sikap). Hal tersebut mendapat perhatian dari pemerintah, terbukti dengan diadakannya pendidikan karakter pada setiap tingkat pendidikan. Begitu juga dalam pembelajaran matematika, ketika siswa berusaha menyelesaikan suatu masalah matematis, dibutuhkan rasa percaya diri, rasa ingin tahu, ulet, melakukan refleksi atas cara berpikir. Sikap-sikap yang ditunjukan siswa tersebut di dalam matematika disebut dengan disposisi matematis. 
Pada penelitian ini akan diukur disposisi matematis siswa meliputi rasa percaya diri, fleksibel dalam menyelidiki matematis dan mencari alternatif metode, tekun mengerjakan tugas matematis, menunjukan minat rasa ingin tahu, dan daya temu, dan memonitor, merefleksikan pengetahuan dan penalaran sendiri.

\section{METODE PENELITIAN}

Penelitian ini adalah penelitian eksploratif dengan pendekatan kualitatif. Penelitian ini dilaksanakan di MTs Asy-syafi'iya Kendari. Waktu penelitian dilaksanakan pada saat semester ganjil Tahun Pelajaran 2020/2021. Sumber data dalam penelitian ini adalah sumber data primer yakni guru dan siswa sedangkan sumber data sekunder yakni dokumentasi. Subjek penelitian adalah 3 (tiga) orang siswa yang terdiri siswa yang mempunyai disposisi matematis tinggi, sedang dan rendah. Instrumen terbagi dua, yaitu instrumen utama yakni peneliti dan instrument bantu yakni angket disposisi matematis, tes pemahaman matematis pada materi Bentuk Aljabar, dan pendoman wawancara. Untuk menjamin keabsahan data, maka dilakukan triangulasi. Triangulasi dilaksanakan dengan menggunakan triangulasi waktu, dengan cara memberikan masalah yang setara dengan kepada subjek untuk diselesaikan pada waktu yang berbeda. Teknik pengumpulan data dalam penelitian ini adalah pemberian tes kemampuan komunikasi matematis pada materi Lingkaran dan wawancara semi terstruktur. Instrumen tes dikonsultasikan dan divalidasi kepada beberapa ahli. Yang dimaksud ahli adalah dosen pendidikan matematika.

Teknik analisis data yang digunakan adalah mengacu pada konsep Milles \& Huberman (dalam Sugiyono, 2014:274) yang mengklasifikasikan analisis data dalam tiga langkah berikut;

1. Reduksi data (Data Reduction)

2. Penyajian data (DisplayData)

3. Penarikan kesimpulan (Verifikasi)

\section{HASILDAN PEMBAHASAN}

\section{Cuplikan Hasil Wawancara dan Pengamatan}

\section{a. Subjek Pertama DisposisiMatematis Tinggi (DMT)}

Pada saat menyelesaikan soal, subjek DMT mengingat-ingat pengetahuan sebelumnya, bahwa untuk menyelesaikan soal harus menentukan diketahuinya dan pemisalan dalam soal, agar dalam menjawabnya terarah.Di sini terlihat bahwa subjek DMT mampu bekerja secara baik dengan konsep yang tepat. Selain itu, subjek DMT 
dapat melakukan penggeneralisasian dari soal cerita tersebut dengan menentukan nama variabel yang ditanyakan pada soal, bahwa untuk menentukan nilai variabel perlu merujuk ke rincian yang lebih khusus. Terlihat bahwa subjek DMT mampu membuat model matematikanya dengan benar dan menyelesaikan masalah dengan tepat dan hasil yang benar. Selain itu, subjek DMT menentukan variabelnya persamaan aljabar menggunakan huruf $x$ karena cara itulah yang DMT pahami. Dalam menjelaskan penyelesaian soal tersebut, subjek DMT membuat model matematikanya dan langkah-langkahnya dengan seksama untuk mengumpulkan sejumlah informasi.Sheingga subjek DMT mampu memaknai model matematika itu sendiri.Dalam memaknai model matematika yang dibuat tersebut, subjek DMT mampu menganalisis hubungan setiap langkah penyelesaiannya. Ketika subjek DMT melakukan proses penyelesaian, subjek DMT telah mampu mengartikan apa yang diketahui dan ditanya dalam soal cerita dan mengubahnya dalam bentuk matematis sesuai yang ada pada soal. Dari lembaran jawabannya, subjek DMT mengecek kembali hasil jawabannya dengan memasukan kembali nilai-nilai variabel yang ditanyakan ke dalam persamaannya.Subjek DMT juga bisa mengumpulkan semua informasi dan memberikan kesimpul.

\section{b. Subjek Pertama DisposisiMatematis Sedang (DMS)}

Data subjek DMS dalam menyelesaikan soal nomor 1 yang telah dipaparkan di atas adalah data tereduksi, yaitu data yang sudah dipilih dan selanjutnya data disajikan berikut ini. Pada saat menyelesaikan masalah soal nomor 1 pada wawancara, subjek DMS mengingat-ingat pengetahuan sebelumnya bahwa untuk menyelesaikan soal harus menentukan diketahuinya dan yang ditanyakan dalam soal, agar dalam menjawabnya terarah. Namun disini terlihat bahwa subjek DMS tidak mampu bekerja secara baik sehingga terjadi kesalahan konsep. Selain itu, subjek DMS melakukan penggeneralisasian dari soal cerita tersebut dengan menentukan nama variabel dalam dua variabel yang tidak sesuai informasi dan yang ditanyakan pada soal. Terlihat bahwa Subjek DMS mampu membuat model matematikanya namun terjadi kekeliruan dalam hal pemahaman pembuatan model matematikanya.Subjek DMS menentukan variabelnya persamaan aljabar menggunakan huruf $x$ dan $y$ karena cara itulah DMS pahami. Dalam menjelaskan penyelesaian soal tersebut, subjek DMS membuat model matematikanya dan langkah-langkahnya dengan mengumpulkan sejumlah informasi.Namun subjek DMS tidak mampu memaknai model matematika itu sendiri.sehingga, pada nilai akhirnya yang didapat DMS benar namun langkah-langkah penyelesaiannya keliru. Ketika subjek DMS melakukan proses penyelesaian, dengan kesalahan konsep yang diigunakan subjek DMS mengartikan apa yang diketahui dan ditanya dalam soal cerita dan mengubahnya dalam bentuk matematis sesuai yang ada pada soal. Dari 
lembaran jawabannya, subjek DMS tidak yakin dari nilai yang diperoleh sehingga mengecek kembali hasil jawabannya dengan memasukan kembali nilai-nilai variabel yang ditanyakan dari soal kedalam persamaan dan mendapatkan nilai benar.Namun subjek DMS tidak mengumpulkan semua informasi dan menyimpulkannya.

\section{c. Subjek Pertama DisposisiMatematis Sedang (DMS)}

Pada saat menyelesaikan masalah soal nomor 1 pada wawancara, DMR sudah tidak dapat menginterpretasi makna solusi matematis, sehingga prosesnya tidak utuh karena hanya memperkirakan jawaban tanpa memahami bagaimana proses memperolehnya. Subjek DMR tidak mampu bekerja secara baik sehingga terjadi kesalahan pada konsep. Selain itu, subjek DMR melakukan penggeneralisasian dari soal cerita tersebut dengan menentukan nama variabel dalam dua variabel yang tidak sesuai informasi dan yang ditanyakan pada soal. Subjek DMR mampu membuat model matematikanya namun terjadi kekeliruan dalam hal pemahaman pembuatan model matematikanya yang akhirnya hasilnya tidak benar atau keliru. Subjek DMR menentukan variabelnya persamaan aljabar menggunakan huruf $x$ dan $y$ karena cara itulah DMR pahami. Dalam menjelaskan penyelesaian soal, subjek DMR membuat model matematikanya dan langkah-langkahnya dengan mengumpulkan sejumlah informasi yang salah.sehingga, subjek DMR tidak mampu memaknai model matematika itu sendiri. Subjek DMR melakukan proses penyelesaian dari model matematika yang sangat keliru. Dari lembaran jawabannya, dengan percaya diri nilai yang diperoleh, subjek DMR mengecek kembali hasil jawabannya dengan memasukan kembali nilai-nilai variabel yang ditanyakan dari soal kedalam persamaan dan mendapatkan nilai salah.Selain itu, subjek DMR tidak mengumpulkan semua informasi dan menyimpulkannya.

\section{Karateristik Pemahaman Matematis Subjek DMT}

Subjek disposisi matematis tinggi (DMT), mampu membuat pemisalan matematika dengan benar.Subjek DMT memisalkan harga buku adalah $x$ maka 4 buku adalah $4 x$; harga 1 pensil adalah $1 / 3 x$. Berdasarkan penyajian data, dapat dikatakan bahwa DMT memenuhi indikator 1 (satu) pemahaman matematis, yaitu mampu memahami konsep-konsep dan fakta matematika dalam dalam istilah konsep dan fakta matematika yang lebih sederhana.

Setelah membuat pemisalan matematika subjek DMT mampu membuat model matematika dengan benar maksudnya menafsirkan kalimat bahasa Indonesia yang ada dalam soal cerita kedalam bentuk matematis. Hal ini, menunjukan subjek DMT sudah mampu membuat hubungan logis antara fakta dan konsep yang berbeda.

Pada tahap melaksanakan penyelesaian, subjek DMT melakukan operasi aljabar terhadap model matematika yang dibuat untuk mendapatkan nilai $x$. Dari langkah yang dilakukan, menggambarkan bahwa subjek DMT mampu menyediakan 
bukti penghitungan matematika secara logis dengan penjabaran yang tepat. Dari proses yang telah dilakukan menunjukkan bahwa subjek DMT mampu mengaitkan hal yang telah diketahui sebelumnya ketika menemukan sesuatu yang baru baik didalam maupun diluar matematika.

Subjek DMT pada tahap ini menyimpulkan hasil dari permasalahan yaitu dengan menjawab harga satu buku dan satu pensil.Dan untuk menguji hasil jawaban, subjek DMT mensubtitusikan nilai-nilai yang diperoleh ke dalam model matematika yang dibuat sebelumnya. Dari proses yang telah dilakukan subjek DMT menunjukkan bahwa mampu mengidentifikasi prinsip-prinsip dalambagian tertentu dari matematika yang membuat semuanya saling berkaitan dalam menyelesaikan suatu masalah matematika.

Berdasarkan analisis hasil kerja subjek DMT, maka di dapatkanlah bahwasanya subjek DMT sudah mampu memahami dan menyelesaikan permasalahan terhadap masalah yang diberikankan.Maka dapat disimpulkan bahwa subjek DMT mempunyai kemampuan pemahaman matematis.

\section{Karateristik Pemahaman Matematis Subjek DMS}

Subjek disposisi matematis sedang (DMS), menuliskan apa yang diketahui, membuat pemisalan. Akan tetapi, DMS tidak teliti memahami masalah pada soal sehingga terjadi kesalahan konsep.Subyek DMS memisalkan buku adalah $x$ dan pensil adalah $y$. Berdasarkan penyajian data, dapat dikatakan bahwa DMS tidak mampu memahami konsep dan fakta matematika dalam hal konsep dan fakta matematika yang lebih sederhana.

Ketidak telitian dalam memahami soal subjek DMS membuat model matematika yang salah.Hal ini, menunjukan subjek DMS tidak mampu membuat hubungan logis antara fakta dan konsep yang berbeda menyelesaikan masalah.

Pada tahap penyelesaian subjek DMS mencoba menyelesaikan permasalahan yang sudah diketahui dan melakukan pengoperasian terhadap model matematika salah yang telah dibuat. Dari proses yang telah dilakukan subjek DMS, menunjukkan kesalahan komputasi yaitu salah dalam melakukan perhitungan dan hasil akhir yang kurang tepat. Dalam hal ini, subjek DMS tidak mampu mengaitkan hal yang telah diketahui sebelumnya ketika menemukan sesuatu yang baru baik didalam maupun diluar matematika.

Pada tahap akhir penyelesaian subjek DMS tidak menyimpulkan hasil dari permasalahan namun hanya menguji hasil jawaban, dimana subjek DMS mensubtitusikan nilai yang diperoleh kedalam model matematika dan hasilnya benar meskipun dengan prosedur dan konsep yang salah.

Siswa yang mempunyai disposisi matematis sedang tidak mampu memenuhi seluruh indikator pemahaman matematis.Hal ini terlihat dari salah memaknai suatu 
fakta yang ada pada soal, salah dalam penggunaan konsep dan salah dalam melakukan pengoperasian. Pada sisi lain, kesalahan jawaban siswa mungkin dikarenakan proses menerima dan mengolah informasi yang tidak tepat namun tetap digunakan siswa untuk alasan menjawab permasalahan yang diberikan. Kesalahan lain yang mungkin dilakukan adalah siswa kurang teliti dalam melengkapi dengan prosedur pada jawaban yaitu ketidakteraturan dalam menulis atau mengurutkan langkah-langkah dalam penyelesaian jawaban, sehingga menyebabkan jawaban tidak tepat.

\section{Karateristik Pemahaman Matematis subjek DMR}

Subjek disposisi matematis rendah (DMR), tidak teliti memahami masalah pada soal sehingga terjadi kekeliruan dalam pemisalan.Subyek DMR memisalkan buku adalah $x$ dan pensil adalah $y$. Berdasarkan penyajian data, dapat dikatakan bahwa DMR tidak memenuhi indikator 1 (satu) pemahaman matematis.

Pada tahap membuat hubungan logis antara fakta dan konsep yang berbeda DMR, karena ketidak tidak telitian dalam membaca soal, sehingga membuat model matematika yang salah.Subjek DMR tidak mampu bekerja secara mental dalam membuat model matematika terlihat dalam mebuat persamaan matematika yang salah.

Pada tahap melaksanakan penyelesaian, yang dilakukan subjek DMS melakukan operasi aljabar untuk menentukan nilai $x$ dan $y$ tehadap model matematika dari masalah aljabar.Dari langkah yang dilakukannya ini, menggambarkan bahwa subjek DMS tidak mampu menyediakan bukti penghitungan matematika pengoperasian yang tidak tepat. Dari proses yang telah dilakukan subjek DMS, menunjukkan bahwa DMS tidak mampu mengaitkan hal yang telah diketahui sebelumnya ketika menemukan sesuatu yang baru baik didalam maupun diluar matematika.

Pada tahap mengidentifikasi prinsip-prinsip dalam bagian tertentu dari matematika yang membuat semuanya saling berkaitan dalam menyelesaikan suatu masalah matematika, Subjek DMS tidak menyimpulkan hasil dari permasalahan namun hanya menguji hasil jawaban, dimana subjek DMS mensubtitusikan nilai yang diperoleh kedalam model matematika yang telah dibuat dan hasil yang didapat salah karena menggunakan prosedur dan konsep yang salah.

Terkait dengan pemahaman matematis, uraian di atas menunjukkan bahwa subjek disposisi matematis rendah adalah siswa yang tidak mampu menangani secara efektif peristiwa dan situasi yang mereka hadapi, menjauhkan diri dari menyelesaikan tugas yang sulit, aspirasi yang rendah dan komitmen yang lemah terhadap tujuan yang dicapai.Akibatnya pada saat diwawancarai terkait dengan pemahaman selalu memberikan jawaban yang kurang tepat atau bahkan cenderung 
memberikan yang tidak sesuai dengan langkah-langkah pemecahan masalah. Pada sisi lain, subjek disposisi matematis rendah tidak mampu memenuhi semua indikator pemahaman matematis. Hal ini dapat dilihat dari siswa membuat pemisalan yang tidak tepat, tidak membuat apa yang diketahui dan yang ditanyakan, serta tidah mampu menjalankan atau mengoperasikan permasalahan soal cerita, serta membuat kesimpulan yang tidak tepat.

Berdasarkan analisis hasil kerja subjek DMR, maka di dapatkanlah bahwasanya subjek DMR tidak mampu memahami dan menyelesaikan permasalahan terhadap masalah yang diberikankan. Dengan kata lain subjek DMR mempunyai kemampuan pemahaman matematis yang sangat rendah.

Berdasarkan hasil penelitian diperoleh bahwa subjek dengan disposisi matematis tinggi memiliki pemahaman matematis yang lebih baik.Hal ini disebabkan kemampuan siswa yang tanggap dalam memahami masalah yang diberikan. Hal ini sesuai dengan hasil penelitian Saryati, Budiyono, dan Riawan (2020) menyatakan bahwa seorang siswa yang memiliki disposisi matematis tinggi biasanya mempunyai sikap kegigihan yang tinggi untuk menyelesaikan permasalahan yang mereka hadapi dalam pembelajaran matematika. Sedangkan hasil dari analisis kerja dan wawancara terhadap siswa berkategori dengan kemampuan sedang dan rendah menunjukkan bahwa siswa melakukan kesalahan pemahaman konsep dan kesalahan operasi yang diakibatkan kesalahan melakukan analisis terhadap soal yang diberikan. Kesalahan jawaban siswa dikarenakan proses menerima dan mengolah informasi yang tidak tepat namun tetap digunakan siswa untuk alasan menjawab permasalahan yang diberikan. Hal lain yang menjadikan jawaban siswa salah dan ketidak tepatan dalam mengelola informasi yang diperoleh sehingga melakukan kesalahan dalam operasi hitung aljabar. Kesalahan lain yang mungkin dilakukan adalah siswa kurang teliti dalam melengkapi jawaban, sehingga menyebabkan jawaban tidak tepat. Lemahnya penguasaan siswa terhadap unsur-unsur dalam menyelesaikan soal menunjukkan siswa belum mampu berpikir dan memahami permasalahan soal secara matematis.

\section{KESIMPULAN}

Berdasarkan uraian di atas dapat diambil beberapa kesimpulan bahwa kemampuan Berdasarkan hasil analisis data dan pembahasan, tentang karakteristik kemampuan pemahaman matematis siswa ditinjau dari disposisi matematis dapat disimpukan sebagai berikut:

1. Subjek disposisi matematis tinggi (DMT) mampu memahami konsep-konsep dan fakta matematika dalam istilah konsep dan fakta matematika yang lebih sederhana yakni siswa dapat membuat pemisalan matematika dengan benar; mampu membuat hubungan logisantara fakta dan konsep yangberbeda yakni 
siswa membuat model matematika dengan benar; mampu mengaitkan hal yang telahdiketahui sebelumnya ketikamenemukan sesuatu yang baru baikdi dalam atau di luar matematika yakni siswa menyelesaikan permasalahan yang sudah diketahui dan dioperasikan; mampu mengidentifikasi prinsip-prinsip dalambagian tertentu dari matematika yang membuat semuanya saling berkaitan dalam menyelesaikan suatu masalah matematika yakni siswa menyimpulkan hasil dari permasalahan yang sudah diselesaikan;

2. Subjek disposisi matematis sedang (DMS) dan subjek disposisi matematis rendah (DMR) tidak mampu memenuhi semua indikator pemahaman matematis yakni siswa tidak dapat membuat pemisalan matematika dengan benar, siswa tidak dapat membuat model matematika dengan benar, siswa tidak dapat menyelesaikan permasalahan yang sudah diketahui dan dioperasikan, dan siswa tidak dapat menyimpulkan hasil dari permasalahan yang sudah diselesaikan

Berdasarkan kesimpulan di atas, maka dapat diberikan saran-saran sebagai berikut.

1. Untuk meningkatkan kemampuan pemahaman matematis siswa sebaiknya guru terlebih dahulu harus memperbaiki sikap siswa terhadap pembelajaran matematika sehingga siswa memiliki sikap yang positif terhadap pembelajaran matematika.

2. Tes disposisi matematis cukup penting bagi pembelajaran reguler maupun diluar sekolah, karena dapat menjadi tolak ukur dalam mempelajari karakteristik siswa terhadap kemampuan matematika yang dimilikinya.

3. Disposisi matematik penting untuk dikembangkan karena dapat menunjang keberhasilan peserta didik dalam belajar matematika. Dengan menggunakan disposisi matematik yang dimiliki oleh peserta didik, diharapkan peserta didik dapat menyelesaikan masalah, mengembangkan kegiatan kerja yang baik dalam matematika, serta bertanggung jawab terhadap belajar matematika.

\section{Daftar Pustaka}

Depdiknas, (2006). Kurikulum Tingkat Satuan Pendidikan. Jakarta: Depdiknas.

Hudojo, H., (2005). Pengembangan Kurikulum dan Pembelajaran Matematika. Malang : UM Press.

Hendriana, H., Rohaeti, E., \& Sumarmo, U., (2017). Hard Skills dan Soft Skills Matematik Siswa. Bandung: Refika Aditama.

Idris, N., (2009). Enhanching Student, Understanding In Calculus Trough Writing.International Electronic Journal of Mathemathics Education.4, (1). Hal 36-56.

Neneng, T. R., (2017). Analisis Kemampuan Pemecahan Masalah Matematis Pada Materi Aljabar SMP Berdasarkan Disposisi Matematis.Pasundan Journal of Research in Mathematics Learning and Education Volume 2 Nomor 2, Desember 2017 ISSN 2548-2297. 
Shodikin, A., (2015). Strategi Abduktif Deduktif pada Pembelajaran Matematika dalam Peningkatan Disposisi Siswa. Jurnal Madrasah. Vol. 7(2), pp. 181202.

Sugiyono, (2014).Metode Penelitian Kombinasi (Mixed Methods). Bandung: Alfabeta.

Suherman, E.,Turmudi, Suryadi, D., Herman, T., Suhendra, Prabawanto, S., Nurjanah, \& Rohyati, A., (2003). Strategi Pembelajaran Matematika Kontemporer. Bandung : JICA-UPI.

Walle, V., \& Jhon A., (2008).Matematika Sekolah Dasar dan Menengah Pengembangan Pengajaran. Jakarta: Erlangga.

Yuliati, P. \& Fahinu, (2015).Pengaruh Pendekatan Saintifik Terhadap Kemampuan Pemahaman Matematik Siswa Kelas VIII SMP Negeri 9 Kendari pada Materi Operasi Aljabar. Jurnal Penelitian Pendidikan Matematika Volume 3 No. 3, Hal 153-166 